\title{
Doing Archival Research in The Gambia: Locating and Appraising the Sources
}

\section{Fazendo pesquisa de arquivo na Gâmbia: localizando e avaliando fontes}

\author{
Hassoum Ceesay*
}

\begin{abstract}
This article discusses the various archival research resources in The Gambia. It seeks to introduce to future researchers on The Gambia the wide choice of archival and secondary sources available in the country.
\end{abstract}

Keywords: oral sources, Gambia, African history, Kaabu

Resumo: Este artigo discute os vários recursos de pesquisa de arquivo na Gâmbia. Ele procura apresentar aos futuros pesquisadores a ampla escolha de fontes primárias e secundárias disponíveis nos arquivos da Gâmbia.

Palavras-chave: Arquivos, fontes, História Africana, Gâmbia, Kaabu

\section{Introduction}

Since the 1930s, Western scholars have become enamoured of doing research in The Gambia on history, anthropology, linguistics, theology and politics. ${ }^{1}$ Of late also, especially since the establishment of the University of The Gambia in 2000, there is emerging a little amount of archival research by local scholars and students. The fall of the feared Gambian despot, Yahya Jammeh in 2017 has generated to an influx of foreign researchers who now feel safe to work in the country. In a nutshell, there is currently a fair amount of research interest on The Gambia by local and foreign scholars which is set to

(c) EY Direito autoral e licença de uso: Este artigo está licenciado sob uma Licença Creative Commons. Com essa licença você pode compartilhar, adaptar, para qualquer fim, desde que atribua a autoria da obra, forneça um link para a licença, e indicar se foram feitas alterações. 
grow bigger. Yet, there is hardly any academic writing on the state of archival resources in the country. While scholars have delved into the potentials and pitfalls of doing archival research in Guinea Conakry, for example, and other neighbouring states, there is hardly any literature on similar issues in The Gambia $^{2}$. What little has been written on the subject of archival research in the country cover the emergence of The Gambia National Museum and Oral Archives in the 1960s, the state of the tiny photographic collection in the Gambia National Archives and an anthropologist's experience with field work in the country during the period 1946 to $2006^{1}$. Although seminal, these few studies were not meant to be a guide to future archival researchers in the country. Rather they critique the administration and state of conservation of the collections. There is a gap in the scholarship of archival research resources in the country. This paper seeks to explore the potentials for research in, and nature of archival resources in The Gambia such as the National Archives, Oral Archives of the Research and Documentation Division(RDD) of the NCAC, Gambia National Library, Gambia Radio and Television Services, the Department of Information, Gambia National Museum. It is meant to be a modest guide to local and foreign researchers on The Gambia. I intend to reveal the location, content, accessibility and conditions of the various archives in the country, and thereby also encourage archival research in The Gambia. $^{2}$

\section{The Gambia National Archives, Banjul}

It was established as The Records Office (renamed Gambia National Archives in 1976 and National Record Service in 2002) in 1966 with the assistance of the British government who sent an archivist soon after independence to help start the collection. Dr Florence Mahoney, the first Gambian woman $\mathrm{PhD}$, who gained her doctorate in history from University of London in 1963, was frustrated by the fact that all the archival records were dispersed in various government departments while she was doing her research. After independence, she used family connections to convince the new government of Sir Dawda Jawara to establish an archive. The government was also eager to do so because it saw an archive as another institutional symbol of independence like the future National Museum and Gambia National Troupe. Newly independent African countries were eager to re-assert their nationhood through the re-appropriation of the historical and cultural narrative. This they did by establishing national museums, archives, libraries and dance troupes which became symbols of state just like the flags and anthems.

Soon archives grew from a one man unit under the office of the Prime Minister to a fully fledged department of government. Italian scholar Alice Bellagamba correctly observes that 'this archive constituted an initial step in the establishment of a shared national memory, though it was mainly from 
the colonizers' viewpoint' in content, context and approach'. ${ }^{3}$ The Gambia National Archives for example, only hold colonial era documents, newspapers and photographs. It does not have an oral section where the history of the pre-colonial era could be accessed in tape recordings of informants such as griots. Liam Buckley, who studied the tiny photo-collection of the Gambia National Archives recounts that while the colonial government was efficient in generating documents, "it was less efficient in preserving them into a useable or accessible format such that the received wisdom among officials was to destroy documents and not keep them'.${ }^{4}$ As will be seen later in this study, neither were the post independence governments keener in preserving this national heritage for future generations. Thus it is safe to argue that the initial euphoria which greeted the creation of such identity symbols of independence soon evaporated and these were now left at the mercy of the elements and poor funding.

\section{From 1816 onwards}

The National Archives' holdings date from 1816 when the British purchased Banjul as a new settlement; a bulk of the holdings is correspondence from the Colonial Secretary's Office in Bathurst, to London and vice versa. Thus the archive ably asserts the colonial approach to Gambian and indeed African history: its study should start with the European contact or the very onset of the colonial state!

Newspapers published in Bathurst and Banjul from 1922 to date also form part of the holdings, so are records of deaths, births, in the colony, land records, the reports of colonial officials like commissioners, chiefs and heads of departments. The archives cover almost all aspects of Gambian life under colonial rule. The obsession of the British colonial rulers with record keeping has to be seen in the context of the paranoid reflex of colonial rule which put much premium on 'law and order' and therefore to have everybody, anything observed and documented.

Sadly, since 1967, very little new material has been accessioned due to lack of space and capacity. An embarrassing measure of the degree of neglect of institutions of memory like the archives by the post colonial rulers is this fact of the archives collection are frozen to 1967, and its poor location.

The National Archives premises are tucked in the Quadrangle, the drab set of two storey buildings which house government Ministries. It is yet to move to purpose built buildings. Its warehouses are full of thousands of files generated since independence ready for shelving. This means that the task is much easier for a researcher on colonial history than one on the post independence period. This paradox cannot go without a comment.

In the past two decades there has been a concerted effort by the Gambia government to re-assert its independence from 'neo-colonialism', yet, the 
Gambia National Archives remains stuck in the colonial period with almost no files available for researchers on any topic since independence. While the colonial period is well illuminated by over 5000 files of colonial records, the history of the country in the past fifty years since independence in 1965, is hidden inside boxes holding files which have either not yet been de-accessioned or have no space in the tiny spaces available for the archives holdings. The post colonial state is yet too timid to reveal its 'official secrets' to researchers, it seems. In 1999, the government further relegated the archives to the recesses of the state by lumping it together with the Current Records Office to form a new department called National Records Service (NRS). Now, the word 'archive' no longer exist in the official nomenclature.

\section{Access issues}

This notwithstanding, the National Archives is perhaps the most accessible in the sub-region for a researcher as the paper work is so limited that it takes less than 10 minutes for one to have a' readers' ticket' and 'production form' needed to access files at no fee. Readers only need to show an ID such as passport to get the ticket. This lack of bureaucracy distinguishes it from other state archives in neighbouring countries like Guinea Conakry where an archives' user fee is paid in addition to other requirements such as passport sized photos; or in Ghana were research permits or institutional affiliation testimonials are required at a cost also. ${ }^{5}$ Due to the small volume of archival use, the small search room in Banjul is hardly ever crowded; thus there is usually no queue or long waiting lines to use the archives. In the past year, much effort has been made to make the search room comfortable with new furniture, better lighting and curtains.

Reproductions of documents by photocopy or digitization are permitted at a token fee of D2.00 per page. Another advantage of the archives is that it is accessibly located in the centre of Banjul, in the government secretariat called the Quadrangle close to the National Museum. The working environment is usually quiet. When the archives' photocopier is not working, the records clerks are usually kind enough to escort files to a nearby copy shop for copies to be made for the researcher.

The Gambia National Archives has an index and a catalogue. There is an archives' index which gives the general headings for the whole collection and then a more detailed catalogue which gives the numbers and names of the files available. The biggest collection in the holdings are marked "CSO" for "Colonial Secretary's Office", which holds all the correspondence to and from the Colonial Secretary in Banjul during colonial rule. It is numbered CSO1 to CSO24. Another big collection is the "NGP" for Non-Government Publications which includes the entire newspaper collection in the archives except the government owned Gambia News Bulletin. The NGP section is 
the most up-to-date as it contains newspapers published in Banjul since 1922 to date. Government publications such as the Gazette, Sessional Papers, Ordinances, Staff List and Reports of Commissions of Inquiry fall under the heading 'Government Publications' or PUB. The catalogue is arranged in alphabetical order and follows the government departments' names such that the AGR files series contains all material on Agriculture department from 1924 to 1970; AU contains the files on the Audit Department from 1948 to 1973; and BIA contains files on Banjul International Airport from 1944-1978.

For scholars interested in issues related to the former Protectorate or provinces such as chieftaincy, and customary law the reports by the Colonial Commissioners in each of the Gambian administrative divisions are catalogued as CRM for files on MaCcarthy Island Division; CRN for files on North Bank Division; CRS for South Bank Division and CRU for Upper River Division. These files could be complemented with files from the CSO 18 titled 'Historical Notes on the Provinces' which give detail historical, economic and social backdrop to the 36 Gambian districts including ruling families, creeks, lakes and major economic activities during the colonial period. Disappointingly, only two of the score of Gambian political parties since 1951 have any useable deposit in the archives. The series PP1 has materials pertaining to the Peoples' Progressive Party(PPP) which ruled Gambia from 1962 to 1994; while PP2 has a few folios on the small Marxist-Lennist party called PDOIS. Likewise, there are no records yet from the Gambia Appeal Court, Forestry Department, and Accountant General's Department. The photo collection is tiny with the series Pho1 having only 51 items dated from 1900 to 1957 ! Most of the photos have been lost to theft or poor conservation and more than half of the collection does not have captions.

Sadly, at the time of writing, the catalogue and index are in tatters. They have not been updated since 1999, and many pages have come off the clippings and risk being lost creating a debilitating gap for researchers. There is no soft copy of the catalogue, meaning that even if it were to be updated today, it has to be totally retyped again. The very few new acquisitions, mainly newspapers, are written in ink on the margins of the pages of the catalogue. None of the archive's collection is available online or in digital form. Two attempts to digitize parts of the collection have stopped due to lack of funds and staff capacity and frequent power outages. However, an even more serious threat is the lack of trained archivists to run the archives. While its first cohort of staff including the founding Chief Archivist, Mr. Stephen Bahoum were trained archivists and conservators, subsequent staff did not benefit from such specialized training or even if they did, have left the services of government for better paying jobs. Thus the ground staff at the search room has little technical knowledge of archiving and usually could not be of much help to 
researchers who wish to navigate their way through the collection. However, they are a cheerful lot always keen to be of assistance.

In The Gambia, the National Archive is centralized in Banjul. There are no branches in the regions or major towns unlike in other African countries like Ghana or Senegal. This means that all its contents are available in one room and the researcher does not have to incur the extra cost of travelling to other locations up country for any files. As the room housing the archive was not purpose built (a plot of land has been earmarked for a future archives building, outside Banjul), issues of conservation would naturally arise. Many files are so damaged 'owing to the difficulty of guarding against the ravages of insects and the harm done by the damp atmosphere" that they have been removed from use by researchers. ${ }^{6}$ If no immediate remedial action is done, a sizeable chunk of the collections' earliest records would be lost forever.

\section{Nuggets}

The oldest files in the archives still open to researchers date to 1814 under the CSO1/1, and CSO 1/2 folios and cover the frenzied British colonization activities of St. Mary's Island at the mouth of the River Gambia now called Banjul, and MaCcarthy Island, $300 \mathrm{~km}$ upriver, some of the earliest permanent British settlements in West Coast of Africa. The two files contain extracts from letters sent out from Sierra Leone, where the British Governor overseeing British territories in Gambia and Senegal was based, on sundry British imperial pursuits in the West Coast including the treaty which ceded St. Mary's Island (Banjul) to the British in 1816; the British merchants' concern at the Senegambia 'illicit slave trade more cruel and horrid in its nature than one of a more avowed description' which was be carried out by French and Portuguese slavers; and the French -British rivalry for control of the Gambian river port of Albreda. File CSO 1/2 has folios on the 1783 Versailles Treaty of Peace between France and Britain in which Britain gave up her possessions of St. Loius, and Goree (in present day Senegal) to the French in exchange for the French abandoning all claims to James island and Albreda on the River Gambia. This should be useful material for researchers on the $19^{\text {th }}$ century Anglo-French imperial rivalry in Senegambia, which heralded the formal occupation and colonization of Gambia and Senegal by the two powers.

An interesting feature in the National Archives is the sizeable collection of private papers and monographs it holds. A few of the former British civil servants such as John Topp, who was Director of Lands in the 1920 have donated their papers and are available to researchers. The entire works of pioneer American anthropologists on Gambia such as Dr. David Gamble(1922-2011) and Dr. David Ames are also available for use under the catalogue heading 'Non Government Records (NGR)'. Sadly, the 
archives have not yet received any private papers for contemporary Gambian historical figures such as the founding President Sir Dawada Jawara, who led The Gambia from 1962 to 1994 . This is another major gap which must be remedied as soon as possible.

\section{Research Documentation Division (RDD) of National Center for Arts and Culture (NCAC), Fajara}

The creation of a R.D.D Oral Archives grew out of the increasing awareness of concerned Gambians and the Government of the Gambia of several things. Firstly, there had been a growing recognition of the values of oral literature and music by scholars abroad, especially after the publication of Alex Haley's book Roots in 1976 which was based partially on the oral testimonies of a Gambian griot, and a rather belated recognition of the same thing by some Gambians. Secondly, Gambians realized almost too late that the country's traditional culture was rapidly changing. For example, the art of the griot was seriously threatened because of modern communication, cultural innovations, and changing tastes. The griot began to lose interest in reciting history and turned more and more to entertainment. Moreover the village elders and storytellers were finding fewer and fewer of their young people interested or having the time to listen or learn from them. Old people are not like books which can be stored for generations without too much harm waiting until someone can get around reading them. Also, traditional ceremonies, songs, cultural games and dances were being abandoned and the traditional role of craftsman such as weavers, smiths, and cobblers were being undermined by new technologies. Thirdly, there was an increasing desire to preserve for posterity some record of the Gambian past. Since most of the knowledge is transmitted verbally and by demonstration, when elders are no longer around their knowledge would die with them. Scholars have argued that the Gambia Oral Archives was created to counterbalance the colonial oriented Gambia National Archives which did not contain much material on pre-colonial Gambia and which has a clearly Western approach to understanding Gambian history. ${ }^{7}$ According to Green the Oral Archives helps to "balance the preponderance of written records" that historians on The Gambia like himself have to use.

The R.D.D Oral Archives is one of the most formidable in Africa with 6000 cassettes in various aspects of history and culture. ${ }^{8}$ R.D.D holds audio recordings of interviews with elders from The Gambia, the Casamance region of Senegal, and Guinea Bissau on the Gambia's past including the general history of the Gambia, songs, myths and legends, epics, family histories, stories, folk tales, proverbs, riddles, migration and settlement patterns of The Gambia and Greater Senegambia region..$^{9}$ It started as the Cultural Archives in 1971 under the direction of a Research Officer Bakari Sidibe, charged with the collection of 
both oral traditions and materials or objects of culture. In 1974, it was became known as the Oral History and Antiquities Division (O.H.A.D). Subsequent legislation brought about another name change to the R.D.D in 1990.

The collection began with field recordings made by pioneer researchers like David Gamble, Charlotte Quinn, Winnifred Galloway and Donald Wright who deposited copies of the recordings at the Archives starting in 1946. Later, Sidibe and Galloway 'a North American historian attached as a volunteer to the institution' embarked on field recordings throughout The Gambia, Senegal, Mali and Guinea Bissau. Interviews were recorded on tape, and then transcribed by assistant researchers into files. Thus at the Oral Archives, there are tapes and transcribed and translated files of some of these tapes. Not all of the tapes have yet been transcribed and translated from the original African languages of Mandinka, Wollof, Jola into English. This is useful information, if not a warning, to future researchers at the RDD.

\section{Scope and significance}

The majority of the recordings were collected during the 1960s, 1970s and 1980s by Bakari Sidibe who worked as Cultural Archivist and by foreign, mainly British and American scholars, who dutifully deposited copies of their field recordings as required by Gambian research regulations. The material mostly relates to the Empire of Kaabu, a powerful federated kingdom that governed the regions of Gambia, southern Senegal (Casamance) and northern Guinea-Bissau from the late $13^{\text {th }}$ to the mid $19^{\text {th }}$ centuries. Material covered include relations with neighbouring Fuuta Jalon in present-day Guinea-Conakry $\left(18^{\text {th }}-19^{\text {th }}\right.$ centuries $)$; the origins of Kaabu in the $13^{\text {th }}$ century, and the federation's subsequent social structure; the relationship between various ethnic groups in the region dating back at least to the $18^{\text {th }}$ and $19^{\text {th }}$ centuries. The recordings were made between the 1960s and 1980s, but as history in Africa is an oral genre, they certainly relate strongly to pre-industrial societies in this part of Africa.

The recordings also include genealogies of major families and settlements in Gambia, Senegal, Guinea Bissau, traditional knowledge and philosophies and nationalist politics.

\section{Linguistics goldmine}

The wide linguistics diversity of Gambia, Senegal and Guinea Bissau is still under studied by researchers. Linguists believe that this area's languages are more diverse 'in contrast to the more homogeneous Mande hinterland'. The RDD archive preserves a rich collection of audio recordings from speakers born by the end of the 19th century, which document Senegambia's linguistic diversity from earlier times and the period of colonialism. ${ }^{10}$ This author has identified the following languages represented in the audio recordings in the archives. 
Table 1: Senegambian Languages represented in the audio tapes of RDD archives

\begin{tabular}{l|l|l}
\hline No & Language & Percentage of archival collection \\
\hline $\mathbf{1}$ & Mandinka & 80 per cent \\
\hline $\mathbf{2}$ & Wollof & 5 per cent \\
\hline $\mathbf{3}$ & Fula & 12 per cent \\
\hline $\mathbf{4}$ & Jola & 1 per cent \\
\hline $\mathbf{5}$ & Serehuli & 0.5 per cent \\
\hline $\mathbf{6}$ & Aku(Krio) & 1 per cent \\
\hline $\mathbf{7}$ & Manjago & 0.5 per cent \\
\hline $\mathbf{8}$ & Serere & 0 per cent \\
\hline $\mathbf{9}$ & Karoninka & 0 per cent \\
\hline Source: RDD Archives, audit 2016 &
\end{tabular}

It is obvious from the figures above that there is a definite preponderance of information narrated in Mandinka language, which make up 333 per cent of the Gambian population, and is spoken in Southern Senegal and in Northern Guinea Bissau also. This obvious bias could be explained by the fact that the pioneer collector Mr. Bakari Sidibe, who mostly worked alone, was himself a Mandinka which was also the only language he spoke well enough to interview anybody in it. To obviate this lopsidedness, it is imperative that the NCAC works quickly to collect more data in the other Senegambian languages such as Wollof and Fula.

\section{Musical heritage: Gambian women music}

The RDD has a large collection of tapes on music by Gambian songstresses. Women are the custodians of traditional music in The Gambia in that they transmit musical knowledge to the children at the earliest age in life through the lullabies. Moreover, in all the ethnic groups in the country women have peculiar song, dance and instrumentation styles. As evident in this collection, there is indeed a women's style in song and instrumentation or melody which researchers on traditional Gambian music would be interested in. There are certain instruments which are typically associated with women; it is played by women solely. A good example is the neyo, pieces of iron rubbed against one another to produce a clinking sound, which Mandinka solo women singers accompany their songs with. Among the Wollof, the gourd upturned in a pan of water produces a sharp guttural sound when it is beaten by women using their bare hands. This is called mbostan. Both musical 
genres are represented in the collection. In 2013 and 2016, the NCAC have published a selection of women music in the archives into two albums titled 'Gems of the Gambia' Vol. 1 and 2.

\section{Access}

Generally, the N.C.A.C'S policy with regard access and use of the archive is relatively open. Any interested person, scholar, researcher, consultant, student can gain access. Audio and video recordings cannot be copied or removed from the archive. However, transcribed and translated files can be copied at the researcher's cost. The catalogue has just been updated and digitized through a British Library Endangered Archives grant.

For non-resident researchers a research permit issued by the N.C.A.C at a cost of D1000 is required to gain access to the archives upon filling out a two page form available at the NCAC website (www.ncac.gm). Once this fee is paid, N.C.A.C Research Assistants can assist in gaining access to the files and recordings. They can also assist in the transcription and translation of tapes if they are not already transcribed or translated.

\section{Threats}

Due to uncontrolled climatic conditions in the depository, frequent movement of offices and pest infestations the conditions of the archives have over the past years deteriorated..$^{11}$ Many files have been lost to rodents and mould infestation. Some reel-to-reel tapes could not be listened to due to the lack of suitable reel player. The paper transcriptions are beginning to deteriorate, while the room itself is not sufficiently large to allow for adequate and consistent indexing and storage of either the transcriptions or of the cassettes.

The reason for the precariousness of the collection is that the RDD finds it extremely difficult to carry out its mandate or protecting the collection because of an insufficient subvention from the national government of The Gambia. Meanwhile, changes in technology make accessibility to oral documents ever more difficult, with the majority of documents on reel to reel, VHS, and tape-cassettes. Some of the tapes are outdated reel-to-reel tapes with the equipment needed for their utilization proving increasingly hard to find.

Therefore, the NCAC has partnered with the US Embassy in Banjul, the Swedish Folk Music House, and the British Library Endangered Archives Programme to allay the problems. In fact, in 2003, the US Embassy funds enabled the NCAC to migrate the audio and reel to reel tapes to CDs. Also, since 2013, a project to digitize the entire audio and file collection has been ongoing supported by the British Library Endangered Archives programme. The digitizing project consists of the following work: 
1. Scanning and documentation of the scanning

2. Transcription, translation and linguistic analysis of the transcriptions and add them to the sound-files via audacity

3. Re-digitizing missing or corrupted data

4. Catalogue update and digitization

5. Supervision and monitoring

It is envisaged that by the end of 2019, some parts of the collection will be available online.

Below is a sample from the catalogue of the collection based on files/ tapes that has information which is raw data, about a rarely researched area, on local history and if the file has been translated from the local languages to English, to tease the buds of the ardent researcher!

Table 2: Sample entries from the catalogue of RDD

\begin{tabular}{|c|c|c|}
\hline Tape No & Title & Comments \\
\hline $5172-5177$ & $\begin{array}{l}\text { Manjago } \\
\text { Ceremonies }\end{array}$ & $\begin{array}{l}\text { Spoken and performed; oral } \\
\text { tradition, new information; } \\
\text { neither transcribed nor } \\
\text { translated }\end{array}$ \\
\hline $1235-1241$ & Manjago history & $\begin{array}{l}\text { Histories, new information, } \\
\text { rarely researched, on a minority } \\
\text { group, but not transcribed nor } \\
\text { translated }\end{array}$ \\
\hline 5181 & Wollof wedding & $\begin{array}{l}\text { Oral tradition; Spoken and } \\
\text { performed; oral tradition, new } \\
\text { information; neither transcribed } \\
\text { nor translated. }\end{array}$ \\
\hline $\begin{array}{l}5017,0116,0129 ; 1728- \\
1739 ; 1819-1826 ; 1831- \\
1832 \\
\text { These files have restricted } \\
\text { content in table form on } \\
\text { certain } \\
\text { (Jola) families in Kartong }\end{array}$ & History of the Jola & $\begin{array}{l}\text { Histories, new information, } \\
\text { rarely researched, on a minority } \\
\text { group, but not transcribed } \\
\text { nor translated from the Jola } \\
\text { language }\end{array}$ \\
\hline 4912 & Manduar history & $\begin{array}{l}\text { Oral tradition, settlement history, } \\
\text { but not translated or transcribed }\end{array}$ \\
\hline $4863,4849,4823$ & History of Saloum & $\begin{array}{l}\text { Histories, new information, rare- } \\
\text { ly researched, on a major pre-co- } \\
\text { lonial state which has rarely been } \\
\text { researched; but not transcribed } \\
\text { nor translated; raw data }\end{array}$ \\
\hline
\end{tabular}




\begin{tabular}{|c|c|c|}
\hline 4862 & $\begin{array}{l}\text { History of Mbyen } \\
\text { (family) }\end{array}$ & $\begin{array}{l}\text { Family history, oral tradition, } \\
\text { neither translated nor } \\
\text { transcribed; raw material }\end{array}$ \\
\hline 4859 & $\begin{array}{l}\text { History of Sering } \\
\text { Saloum }\end{array}$ & $\begin{array}{l}\text { Personal witness; history; } \\
\text { raw data; interesting and little } \\
\text { researched area. About the Wollof } \\
\text { ethnic group who are under } \\
\text { studied and underrepresented 'in } \\
\text { the collection. }\end{array}$ \\
\hline $4834,4819,4844$ & $\begin{array}{l}\text { History of Sabach } \\
\text { Sanjal }\end{array}$ & $\begin{array}{l}\text { Will be useful for researchers } \\
\text { on the Greater Baddibu, Battle } \\
\text { of Saba 1890s, or local district } \\
\text { histories. }\end{array}$ \\
\hline 4811 & $\begin{array}{l}\text { History of Rip } \\
\text { Baddibu }\end{array}$ & $\begin{array}{l}\text { This is the Wollof part of } \\
\text { the larger pre-colonial } \\
\text { Baddibu state, which is highly } \\
\text { understudied and not well } \\
\text { researched. }\end{array}$ \\
\hline 4802 & History of Saba & $\begin{array}{l}\text { Compare with 'History of Sabach } \\
\text { Sanjal' }\end{array}$ \\
\hline 4803 & $\begin{array}{l}\text { History of Burr } \\
\text { Saloum }\end{array}$ & $\begin{array}{l}\text { Royalty in the pre-colonial Wollof } \\
\text { state Saloum; raw material } \\
\text { which is un-translated and un- } \\
\text { transcribed }\end{array}$ \\
\hline $0486-0487 ; 0463-0475$ & Fula history & $\begin{array}{l}\text { Histories, but the usual staple of } \\
\text { Musa Moloh }\end{array}$ \\
\hline 4766 & $\begin{array}{l}\text { Cherno Baldeh } \\
\text { (chief of Fulladu) }\end{array}$ & $\begin{array}{l}\text { Chiefs' history, colonial history, } \\
\text { raw data, very little published on } \\
\text { Cherno Baldeh }\end{array}$ \\
\hline $4753,4763,4684$ & Fulladu history & $\begin{array}{l}\text { Histories, raw data, but like } \\
\text { Kaabu, Fulladu is an overflogged } \\
\text { horse of Gambian pre-colonial } \\
\text { history }\end{array}$ \\
\hline 4607,4134 & $\begin{array}{l}\text { PPP Youth } \\
\text { movement }\end{array}$ & $\begin{array}{l}\text { Raw data, contemporary history } \\
\text { of Gambian nationalist politics, } \\
\text { a very rare finding in the RDD } \\
\text { collectiition }\end{array}$ \\
\hline 4365,4367 & $\begin{array}{l}\text { Serahuli history } \\
\text { Julangel }\end{array}$ & $\begin{array}{l}\text { Oral tradition in music form- } \\
\text { Serahuli songs }\end{array}$ \\
\hline 4361 & Serahuli folktales & $\begin{array}{l}\text { Raw data, new information as } \\
\text { not much has been researched or } \\
\text { written about on this }\end{array}$ \\
\hline 4346,4359 & Jimara history & $\begin{array}{l}\text { Histories of one of the smaller } \\
\text { of the Kaabu states; raw data; } \\
\text { one of the pre-colonial Gambian } \\
\text { states not well studied. }\end{array}$ \\
\hline
\end{tabular}




\begin{tabular}{|c|c|c|}
\hline 4124 & Trees and herbs & $\begin{array}{l}\text { New information; local } \\
\text { traditional knowledge; raw } \\
\text { data; among the few 'traditional } \\
\text { science' knowledge in the } \\
\text { archive }\end{array}$ \\
\hline $3891-3892$ & History of Niani & $\begin{array}{l}\text { Histories, raw data, not } \\
\text { transcribed nor translated }\end{array}$ \\
\hline $3889-3891,107$ & Baddibu History & Histories, oral tradition, \\
\hline 3871,3862 & $\begin{array}{l}\text { Krio history and } \\
\text { customs }\end{array}$ & $\begin{array}{l}\text { Raw data; histories of a under } \\
\text { studied Gambian group }\end{array}$ \\
\hline 3874 & $\begin{array}{l}\text { Students Days in } \\
\text { Ghana-Mrs Ndow } \\
\text { 1940-1944 }\end{array}$ & Women's history; raw data \\
\hline 3856 & $\begin{array}{l}\text { Early trading in } \\
\text { The Gambia }\end{array}$ & $\begin{array}{l}\text { Economic history of the River } \\
\text { Gambia; raw data; }\end{array}$ \\
\hline 3852 & $\begin{array}{l}\text { Biram Ceesay } \\
\text { Jihadist }\end{array}$ & $\begin{array}{l}\text { Histories; raw data; personality; } \\
\text { one of the little studied Gambian } \\
\text { jihadists of the late } 1800 \text { s }\end{array}$ \\
\hline $3838,3834,3824$ & Bainunka history & $\begin{array}{l}\text { Raw data; histories; on the group } \\
\text { reputed to be the aboriginals of } \\
\text { Foni and Kombo }\end{array}$ \\
\hline 3754 & $\begin{array}{l}\text { History of } \\
\text { Bathurst }\end{array}$ & $\begin{array}{l}\text { Histories, eye witness; raw data; } \\
\text { a rare peep into the early history } \\
\text { of the Gambian capital. }\end{array}$ \\
\hline 3757 & $\begin{array}{l}\text { Diseases in } \\
\text { Bathurst }\end{array}$ & $\begin{array}{l}\text { Social history on the Gambian } \\
\text { capital }\end{array}$ \\
\hline 3679,3689 & $\begin{array}{l}\text { Rev J.C Faye } \\
\text { nationalist } \\
\text { Colonial history }\end{array}$ & $\begin{array}{l}\text { Histories of Gambian } \\
\text { independence politics; } \\
\text { eyewitness; personalities } \\
\text { involved in nationalist struggle. }\end{array}$ \\
\hline 3685 & $\begin{array}{l}\text { Gambian women } \\
\text { in politics }\end{array}$ & $\begin{array}{l}\text { Role of women in Gambian } \\
\text { independence struggle }\end{array}$ \\
\hline 3600 & Chiefs conference & $\begin{array}{l}\text { Chiefs' history, colonial history, } \\
\text { raw data, very little published on } \\
\text { Chiefs in colonial rule }\end{array}$ \\
\hline 3414 & $\begin{array}{l}\text { Gambia in } \\
\text { colonial days }\end{array}$ & $\begin{array}{l}\text { Histories, eye witness of colonial } \\
\text { Gambia mixed with family } \\
\text { genealogy of the Jallows }\end{array}$ \\
\hline 3394 & $\begin{array}{l}\text { Sayerr Jobe } \\
\text { founder of } \\
\text { Serekunda }\end{array}$ & $\begin{array}{l}\text { Family Histories; eye witness; of } \\
\text { the founding family of the huge } \\
\text { Serekunda settlement }\end{array}$ \\
\hline 3928 & Forsters family & $\begin{array}{l}\text { Family Histories; eye witness; } \\
\text { of a leading Krio Banjul } \\
\text { family which produced the first } \\
\text { Gambian lawyer etc. }\end{array}$ \\
\hline
\end{tabular}




\begin{tabular}{|c|c|c|}
\hline $3275,1980,1981$ & $\begin{array}{l}\text { Gambia And } \\
\text { World War } 2\end{array}$ & $\begin{array}{l}\text { Histories; eye witness on World } \\
\text { War Two; quite rare insight }\end{array}$ \\
\hline $3075-3083$ & $\begin{array}{l}\text { Aku history Miss } \\
\text { Julia Williams } \\
\text { first Gambian } \\
\text { matron of Royal } \\
\text { Victoria Hospital }\end{array}$ & $\begin{array}{l}\text { Family Histories; eye witness; of } \\
\text { a leading Krio Banjul family }\end{array}$ \\
\hline 3072,3074 & $\begin{array}{l}\text { I.M Garba- } \\
\text { Jahumpa, } \\
\text { Gambian } \\
\text { nationalist politics }\end{array}$ & $\begin{array}{l}\text { Eye witness; nationalist history; } \\
\text { another rare testimony on history } \\
\text { of Gambian independence } \\
\text { struggle }\end{array}$ \\
\hline 3052 & $\begin{array}{l}\text { Origin of } \\
\text { Jammehs }\end{array}$ & $\begin{array}{l}\text { Family history of Jammeh's who } \\
\text { have produced a famous colonial } \\
\text { chief, Mama Tamba; and a } \\
\text { president of The Gambia; should } \\
\text { be of high interest to researchers. }\end{array}$ \\
\hline $2983-2987$ & Aku history & $\begin{array}{l}\text { Ethnic history; very little of it has } \\
\text { an oral source so these tapes/files } \\
\text { should be of interest }\end{array}$ \\
\hline $\begin{array}{l}2967-2976,1655,1656 \\
1670 ; 076\end{array}$ & Jola history & $\begin{array}{l}\text { Histories, new information, } \\
\text { rarely researched, on a minority } \\
\text { group, but not transcribed nor } \\
\text { translated }\end{array}$ \\
\hline 2733,2736 & Karoninka history & $\begin{array}{l}\text { Histories, new information, } \\
\text { rarely researched, on a minority } \\
\text { group, but not transcribed nor } \\
\text { translated }\end{array}$ \\
\hline 2704,2705 & $\begin{array}{l}\text { Banjul church } \\
\text { history }\end{array}$ & $\begin{array}{l}\text { Religious history of Christianity; } \\
\text { very little of it is found in oral } \\
\text { sources; this should be of great } \\
\text { interest }\end{array}$ \\
\hline $\begin{array}{l}0005,0074,0089,0090 \\
0098,0100,0077,0079 \\
0146,-0150,0162-0167 \\
0060,0587\end{array}$ & Wuli history & $\begin{array}{l}\text { Histories, raw data, not } \\
\text { transcribed nor translated; a } \\
\text { little has been published by } \\
\text { foreign scholars but still not } \\
\text { as widespread as Kaabu, for } \\
\text { example }\end{array}$ \\
\hline 1901-1902 & $\begin{array}{l}\text { Musu Mansas in } \\
\text { Kombo-Sanyang }\end{array}$ & $\begin{array}{l}\text { Women's history; oral tradition; } \\
\text { except for Donald Wright not } \\
\text { much has been written about it. }\end{array}$ \\
\hline $\begin{array}{l}5184,5164 ; 5167,5168 \\
5164-5165\end{array}$ & Wollof culture & $\begin{array}{l}\text { Ethnic history; raw data, Wollof } \\
\text { in Gambia not quite well studied } \\
\text { such as Mandinka for example. }\end{array}$ \\
\hline 4767, 4777; & Fula history & $\begin{array}{l}\text { Histories, but the usual staple of } \\
\text { Musa Molloh }\end{array}$ \\
\hline
\end{tabular}

Source: RDD Catalogue, NCAC 


\section{The Gambia National Library ${ }^{12}$}

The Gambia National Library was initially founded as a book subscription public lending library in Banjul back in 1946 and was run by the British Council. In April 1962 the British Council shut down its office and gave its library to the government. In 1971 the name was changed to The Gambia National Library. In 1974 the British government paid for the construction of a new building, books, equipment and furniture. Its holdings include monographs, important press clippings, reference, maps, magazines, bibliographic services, newspapers. The collections are acquired through gifts, direct purchases, original legal depository, reports, surveys and similar government and agency documents for archiving. Its GAMBIANA section has rare books on Gambia dating to 1850s, and many other publications like thesis, dissertations by Gambians are deposited there. Gambia publishers also deposit their works there. It is a treasure trove for secondary research on all aspects of Gambian life. As yet there is no catalogue which means that researchers would have to rummage through the shelves to find what they need. There is growing call for the new government to build a public library and for the current library in Banjul to become a national library housing the growing collection of Gambiana material. There is a branch of the library at Brikama which contains a few bound volumes of West Africa magazine and New African Magazine, both reliable secondary sources on Gambian politics.

\section{Radio Gambia}

It was created in 1962 as the first radio station in the country. It has vast collection of archival audio recordings of state functions, state visits, old, modern and traditional music, and policy broadcasts by government officials dating from the late 1950s to date. There is no research procedure as extremely few researchers use the archive. Even the radio staffs do not quite well know the contents of this archive since there is currently no history related programme in their schedule and therefore hardly ever need to use the sound archive. The radio archive should be of great interest to researchers on Gambian music tradtions and modern politics and contemporary history. The archive's catalogue is dated and its tiny space could no longer cope with the new material being generated. There is no space for researchers to sit or machines to listen the reel-to-reel tapes, which makes the sound archive very researcher unfriendly. As I write there are plans to digitize the collection thanks to a grant from the British Library Endangered Archives project.

\section{Gambia Television}

It inherited the vast video archives of the Gambia Film Unit, created in 1969, which recorded videos of state functions, and cultural activities and health and environmental promotional films. Since its inception in 1995, 
Gambia Television is also keeping a film archive. However, neither the Film Unit archive nor the television archive is open for research as there is neither the space, nor catalogue or procedure for its use.

\section{Information Department}

Created in 1946 and it published the Gambia News Bulletin which was the newspaper of record for The Gambia through to the late 1980s when it folded up. It has bound volumes of this newspaper published in Banjul from 1943 to 1990. It is indeed a rich source for researchers interested in government point of view on matters in the Gambia before and after independence. The department also has photographs collected by the newspaper's staff photographers dating to the 1970s. Neither newspapers nor the photographs are catalogued. The photos are kept in boxes without index or any guide for retrieval. There is no research procedure and very few people use this archive.

\section{Gambia National Museum}

Created in 1985, it has a vast photo collection of life in Bathurst in the 1930s, Gambian colonial architecture, and state functions. The museum's collection of archaeological artefacts collected from many parts of the country is impressive. The archaeological specimens date to the earliest archaeological digs in The Gambia in the 1960s and are well kept and catalogued Its ethnographic collection provides useful insight into Gambian material culture, while it has rare maps of The Gambia dating to the 1910s. The museum's photo archive is the biggest in the country are many of them are captioned and kept in acid free boxes to ensure durability.

\section{Private archives}

A.E Cham-Joof (1930-2013)

A few Gambians like the late political activist and broadcaster A.E Cham-Joof (1930-2013) kept vast private archives of photos, documents, letters, and books. Mr. Cham-Joof's private archives has documents and photos covering Gambian political life from 1947 to date. His entanglements in nationalist politics as militant of the Gambia Democratic Party from 1951, are reflected in his archive with such documents as minutes of party Executive Committee meetings from 1951 to 1962; election manifestoes of the party in 1954, 1960 and 1962; campaign posters; party membership cards and photos of party functions, leading members and important political figures of Gambia in the late 1950s and early 1960s. As interpreter for Alex Haley, the author of Roots, Mr. Cham-Joof's archives has letters exchanged between him and Haley, and various US media houses such as Newsweek inquiring about issues related to the research for the Roots book. Sadly, none of this collection has been digitized or catalogued. Since his death in 2013, it is feared that the collection will not get the care it deserves and may be imperilled. 


\section{Alhaji Bakari Sidibe (1928-)}

As founder of the Oral Archives of the NCAC's RDD, Mr. Sidibe has kept copies of many of the items in the NCAC archives. Researchers, who fail to find certain items missing in the NCAC archives due to loss or damage, could fill in the gap by using Mr Sidibe's archives located at his house in the Serekunda suburb of Churchill's Town. An added advantage of his archive is that he as the doyen of Gambian historians is always available to guide the researcher and field in questions on various topics.

\section{Family archives}

Family memorabilia could also be found in many homes in Banjul such as at the Carrols, a noted Banjul mercantile Aku family. The scion of the family, Henry Richmond Carrol (died 1913) was one of the richest men in Bathurst. His sons were lawyers and wealthy merchants who founded a newspaper called The Gambia Echo (1932-1968). The Echo was the paper of record in colonial Gambia. There are bound volumes of the newspaper in the family house at Bedford place in Banjul, which trusted researchers could use. In December 2017, the family deposited the 20 volumes of The Gambia Echo(1935-1957) with the National Museum in Banjul for 'safe keeping'. There are currently being analysed and conserved as most of them came heavily damaged by mildew.

Nana Grey-Johnson (1951-) a reputable editor and writer has in private possession the only extant complete collection of Topic Magazine, the first news magazine published in the country between 1989-1991. The magazine circulated at a time when no other newspaper came out regularly in The Gambia in the early 1990s before the advent of The Point in December 1991. It is extremely useful for researchers interested in Gambian politics of the period 1989-1992.

\section{Church archives}

The Anglican Church operates a well maintained archive run by one of the very few trained archivist in the country. Its collection dates to the early 1900, and is particularly strong on the Anglican Church's involvement in education and social welfare, and minutes of synod meetings. The Methodist and Roman Catholic missions also run archives services within their headquarters in Banjul. They remain ill-equipped and sparse in opening hours to impress any serious researcher.

Muslim families of the Jahanke clergy in various locations in the country such as at Bureng, Jarra Sutukung, Kunting villages, $250 \mathrm{~km}$ outside Banjul on the South bank road, have a rich collection of family documents written in Arabic detailing the history and migration patterns of their families to The 
Gambia in the $19^{\text {th }}$ century. However, few researchers have ever consulted these closely guarded documents tucked away in remote villages in rural Gambia.

\section{Conclusion}

For a very long time, foreign scholars dominated the research in The Gambia. The advent of the junta rule in 1994 and the subsequent tyranny it installed forced many scholars, both local and foreign, to avoid archival research in Banjul. Now that the dictatorship has been removed and there is a local university created in 2000 , this is bound to change. As the University of The Gambia and private universities engage in academic research, the archives and libraries will become even more useful and in more demand. However, it is obvious that the archives mentioned above all share the common challenge of inadequate cataloguing, deterioration of collection and lack of qualified staff. Therefore, for scholars and researchers to make the best out of their potential, urgent conservation interventions such as digitizing, staff training and proper cataloguing should be undertaken.

\section{Notes}

* Historiador e curador do arquivo e do Museu Nacional da Gâmbia. Banjul, Gâmbia. E-mail: hceesay@gmail.com

1 See Bellagamba, Alice. 'Before it is Too Late: Constructing and Oral Archive and National Museum in Independent Gambia," Africa Today Vol.52 (2006) No.4, 29-52. See also, Buckley, Liam. 'Objects of Love and Decay: Colonial Photographs in a post-Colonial Archive,' Cultural Anthropology Vol.20 (May, 2005), 249-270, and Gamble, David. A Review of Development Schemes in The Gambia (San Francisco: the author, 2007).

2 This paper was motivated by several issues: chiefly, the African Studies in UK (ASUAK) Scholarly Writing Workshop held in The Gambia in June 2014 and animated by Dr Toby Green of Kings College, London; Prof. Michel Doortmont of Groeningen Univeristy; Prof. Murray Last, Prof. John Parker of SOAS and Dr. Reg Cline Cole of Birmingham University. This writer realized at this workshop that even Gambia based scholars did not know of the existence of some archival resources in their own country. Another motivation came from my reading of Prof. David Conrad's "Archival Research in Guinea-Conakry" published in HiA Vol. 20 (1993) and Dr Graeme Counsel's ' Archival and Research Resources in Guinea, Conakry" published in HiA Vol.36(2009).

3 Bellagamba, op.cit

4 Buckley, op.cit

5 Counsel, Op.cit. p.442

6 Buckley, 252, op.cit

7 Bellegambia, Op.cit; see also Green, Toby, From Essentialism to Pluralism: New Directions in Pre-colonial West African History from the Oral History Archives at Fajara, Gambia, forthcoming(2017); see also Green, Toby, The Rise of The Trans-Atlantic Slave Trade in 
Western Africa, 1300-1589 (Cambridge: Cambridge University Press, 2012); and Sidibe, Bakari, and Winifred Galloway, "The Collection and Processing of Oral Traditions". Oral History and Antiquities Division (OHAD), (Banjul, The Gambia, unpublished report, 1980).

8 Currently, there are efforts to have the RDD inscribed into the UNESCO Memory of the World List.

9 This region covers present day Gambia, Senegal, Mali, Guinea Conakry and Guinea Bissau.

10 Email communication from, Prof. Henning Schreiber of Hamburg University to Baba Ceesay, NCAC September 28, 2017.

11 Since 1998, the Oral Archives have moved offices three times before landing at its present location at Fajara, $15 \mathrm{Km}$ outside Banjul.

12 Since 2013, the official name is Gambia National Library Service Authority, a very long name for the same institution and structures and staff.

Recebido em: 20/12/2017

Aprovado em: 18/02/2018 